\title{
Unravelling the Phytochemical Composition and the Pharmacological Properties of an Optimized Extract from the Fruit from Prunus mahaleb L.: From Traditional Liqueur Market to the Pharmacy Shelf
}

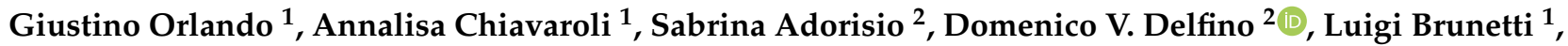 \\ Lucia Recinella ${ }^{1}$, Sheila Leone ${ }^{1}$, Gokhan Zengin ${ }^{3, *}{ }^{-}$, Alessandra Acquaviva ${ }^{1,4}\left(\mathbb{D}\right.$, Paola Angelini ${ }^{5}(\mathbb{D}$, \\ Giancarlo Angeles Flores ${ }^{5}$, Roberto Venanzoni $\left.{ }^{5}{ }^{(}\right)$, Simonetta Cristina Di Simone ${ }^{1}$, Francesca Di Corpo ${ }^{1}$, \\ Andrei Mocan ${ }^{6,7, *(\mathbb{D})}$, Luigi Menghini ${ }^{1, *(1)}$ and Claudio Ferrante ${ }^{1(\mathbb{D})}$
}

check for updates

Citation: Orlando, G.; Chiavaroli, A.; Adorisio, S.; Delfino, D.V.; Brunetti, L.; Recinella, L.; Leone, S.; Zengin, G.; Acquaviva, A.; Angelini, P.; et al. Unravelling the Phytochemical Composition and the Pharmacological Properties of an Optimized Extract from the Fruit from Prunus mahaleb L.: From Traditional Liqueur Market to the Pharmacy Shelf. Molecules 2021, 26, 4422. https://doi.org/10.3390/ molecules 26154422

Academic Editor: Ladislav Kokoska

Received: 29 June 2021

Accepted: 15 July 2021

Published: 22 July 2021

Publisher's Note: MDPI stays neutral with regard to jurisdictional claims in published maps and institutional affiliations.

Copyright: (c) 2021 by the authors. Licensee MDPI, Basel, Switzerland. This article is an open access article distributed under the terms and conditions of the Creative Commons Attribution (CC BY) license (https:// creativecommons.org/licenses/by/ $4.0 /)$.
1 Department of Pharmacy, Botanic Garden "Giardino dei Semplici", Università degli Studi "Gabriele d'Annunzio", Via dei Vestini 31, 66100 Chieti, Italy; giustino.orlando@unich.it (G.O.); annalisa.chiavaroli@unich.it (A.C.); luigi.brunetti@unich.it (L.B.); lucia.recinella@unich.it (L.R.); sheila.leone@unich.it (S.L.); alessandra.acquaviva@unich.it (A.A.); disimonesimonetta@gmail.com (S.C.D.S.); francesca.dicorpo@studenti.unich.it (F.D.C.); claudio.ferrante@unich.it (C.F.)

2 Section of Pharmacology, Department of Medicine and Surgery, Foligno Nursing School, University of Perugia, 06100 Perugia, Italy; adorisiosabrina@libero.it (S.A.); domenico.delfino@unipg.it (D.V.D.)

Department of Biology, Science Faculty, Selcuk University, Campus, Konya 42130, Turkey

4 Veridia Italia Srl, Via Raiale 285, 65100 Pescara, Italy

5 Department of Chemistry, Biology and Biotechnology, University of Perugia, 06100 Perugia, Italy; paola.angelini@unipg.it (P.A.); giancarlo.angelesflores@studenti.unipg.it (G.A.F.); roberto.venanzoni@unipg.it (R.V.)

6 Faculty of Pharmacy, "Iuliu HaŢieganu” University of Medicine and Pharmacy, 8 Victor Babeş Street, 400012 Cluj-Napoca, Romania

7 Laboratory of Chromatography, Institute of Advanced Horticulture Research of Transylvania, University of Agricultural Sciences and Veterinary Medicine, 400372 Cluj-Napoca, Romania

* Correspondence: gokhanzengin@selcuk.edu.tr (G.Z.); mocan.andrei@umfcluj.ro (A.M.); luigi.menghini@unich.it (L.M.)

Abstract: Prunus mahaleb L. fruit has long been used in the production of traditional liqueurs. The fruit also displayed scavenging and reducing activity, in vitro. The present study focused on unravelling peripheral and central protective effects, antimicrobial but also anti-COVID-19 properties exerted by the water extract of $P$. mahaleb. Anti-inflammatory effects were studied in isolated mouse colons exposed to lipopolysaccharide. Neuroprotection, measured as a blunting effect on hydrogen-peroxideinduced dopamine turnover, was investigated in hypothalamic HypoE22 cells. Antimicrobial effects were tested against different Gram+ and Gram- bacterial strains. Whereas anti-COVID-19 activity was studied in lung adenocarcinoma H1299 cells, where the gene expression of ACE2 and TMPRSS2 was measured after extract treatment. The bacteriostatic effects induced on Gram+ and Gram- strains, together with the inhibition of COX-2, TNF $\alpha, \mathrm{HIF} 1 \alpha$, and VEGFA in the colon, suggest the potential of $P$. mahaleb water extract in contrasting the clinical symptoms related to ulcerative colitis. The inhibition of the hydrogen peroxide-induced DOPAC/DA ratio indicates promising neuroprotective effects. Finally, the downregulation of the gene expression of ACE2 and TMPRSS2 in H1299 cells, suggests the potential to inhibit SARS-CoV-2 virus entry in the human host. Overall, the results support the valorization of the local cultivation of $P$. mahaleb.

Keywords: Prunus mahaleb L.; phenolic profile; chicoric acid; protective effects; anti-bacterial effects; anti-COVID-19 effects 


\section{Introduction}

White Mahlab (Prunus mahaleb L.), also known as English cherry, is a deciduous tree belonging to the Rosaceae family, subfamily Prunoideae. The tree is native to the Mediterranean region, Iran, and Central Asia; however, it is also present in Eastern and Central Europe, where it prefers a hot, dry climate and well-drained soils [1]. P. mahaleb cherry trees are commonly used as rootstock in order to give strength and vigor to the sweet cherry; this practice is particularly diffuse in Southern Italy, in the Apulia region [2]. $P$. mahaleb blooms in mid-spring and ripens in summer, producing small, highly pigmented drupes with a diameter between $8-10 \mathrm{~cm}$, and is not currently used for fresh consumption due to their sour and astringent taste [3]. The color of these fruits change from green to red and finally become black when fully ripe [4]. The fruits are generally small, spherical, juicy and with a flat surface; they also display a high content of anthocyanins. The seed is egg-shaped and pointed and represents a valuable source of proteins $(30.98 \% w / w)$ and fatty acids $(40.40 \% w / w)$. Polyphenols have been found in the leaves, fruits, and root wood as well [5]. The plant is also used in the production of traditional fragrances, lotions, and liqueurs [6]. The traditional liqueur called "Mirinello di Torremaggiore" (Apulia, Italy), prepared via traditional hydroalcoholic maceration of the whole fruit from $P$. mahaleb, displayed an appreciable amount of phenolic compounds, particularly in the solid residues of liqueur production [6]. The kernels of the ground seeds have a characteristic bitter taste and therefore are used as flavoring agents in bagels, cakes, muffins, and in folk medicine as diuretic, antidiabetic, tonic, aphrodisiac, and expectorant agents [4]. The whole fruit displayed scavenging and reducing activity in vitro [3]. This is consistent, albeit partially, with the phenolic composition of the phytocomplex. The in vivo administration of $P$. mahaleb prevented the formation of kidney stones as well [7], whereas in vitro studies conducted on rat kidney cells did not show cytotoxicity up to $50 \mathrm{mg} / \mathrm{mL}$ concentration [8]. However, the lack of any data about the phytochemical composition of the extracts tested on kidney cells requires further studies in order to unravel concentrationdependent effects on cell viability and metabolism [8]. Additionally, multiple studies suggest that herbal extracts rich in phenolic compounds have biocompatibility limits characterized by $\mathrm{LC}_{50}$ values $<20 \mathrm{mg} / \mathrm{mL}$ in different in vitro models $[9,10]$. In this context, an accurate evaluation of the tolerability of $P$. mahaleb extracts is requested. Protective effects induced by $P$. mahaleb fruits were also observed in an experimental paradigm of ulcerative colitis [11]. Specifically, the fruit extract was able to activate the nuclear factor erythroid 2-related factor 2 pathway (Nrf2), a transcription factor deeply involved in antioxidant defense [12]. Phytochemical composition in phenolic compounds and protective effects in the colon also agree with the antiproliferative and antimicrobial effects exerted by other Prunus species, namely P. cerasus [13,14]. Still in analogy with P. cerasus [15], the scavenging, reducing and protective effects induced by $P$. mahaleb also indicate a potential application for counteracting the burden of oxidative stress in the brain, although scientific literature is still lacking in this field. However, Bonaventura et al. [16] showed antineuroinflammatory effects induced by $P$. cerasus extract administration in obese mice. The consumption of $P$. avium fruits stimulated the hypothalamic leptin pathway [17] in obese mice, thus suggesting modulatory effects on energy balance control. Considering the literature data regarding $P$. mahaleb and the pharmacological studies available on different Prunus species, namely P. cerusus and P. avium, a multidirectional study was conducted on the water extract of $P$. mahaleb, prepared via an ultrasound-assisted method for unravelling the phytochemical composition and the limits of biocompatibility, through the use of different toxicological paradigms, and pharmacological properties, in terms of anti-inflammatory and neuromodulatory effects. The water extract was chosen to imitate traditional home-made preparations, namely infusions and decoctions, which may not only be effective and safe due to long-term use, but may also be a novel strategy for the improvement of local botanical chains [18]. Specifically, the experimental conditions for the preparation of the water extract were optimized through the response-surface methodology (RSM) [9], a validated in silico model for predicting ab initio the optimal 
conditions for the plant material extraction. In this context, the RSM approach was applied for optimizing the extraction yield of total phenol and flavonoids, which were assayed via both colorimetric and high performance liquid chromatography coupled to a diode array and mass spectrometer (HPLC-DAD-MS). Colorimetric assays were also performed for measuring intrinsic scavenging and reducing and enzyme inhibition (anti-glucosidase, antiamylase, anti-cholinesterase, and anti-tyrosinase) properties. The enzyme inhibition effects were investigated through a docking approach as well. For docking runs, we considered the prominent phenolic compounds identified and quantified in the extract. Further bioinformatics analyses were conducted for predicting the pharmacokinetic properties of these phytochemicals, especially the capability to cross the blood brain barrier that was considered as a cornerstone for supporting the reported evaluation of the extract protective effects in hypothalamic HypoE22 cells challenged with hydrogen peroxide and added to a cell medium as a pro-oxidant stimulus. In this context, the capability of $P$. mahaleb water extract in contrasting the hydrogen peroxide-induced turnover of dopamine [19] was evaluated. Considering the potential application of $P$. mahaleb in ulcerative colitis, we also investigated the protective effects of the water extract of $P$. mahaleb on isolated mouse colon specimens challenged with lipopolysaccharide (LPS) to simulate in this ex vivo model the burden of oxidative stress and inflammation occurring in ulcerative colitis [20]. The gene expression of cycloxygenase-2 (COX-2) and tumor necrosis factor- $\alpha$ (TNF $\alpha)$, deeply involved in colon inflammation [21], were measured. Additionally, the present study considered the evaluation of the gene expression of vascular endothelial growth factor $A$ (VEGFA) and hypoxia-inducible factor $1 \alpha(\mathrm{HIF} 1 \alpha)$, which are well-known angiogenetic factors playing a pivotal role in the inflammatory to cancer transition in different tissues, including the colon [22]. The human colon cancer HCT116 cell line was also exposed to the present water extract in order to explore eventual antiproliferative effects. In this regard, it is sensitive to highlight the potential efficacy of an adequate intake of fruit as a strategy to prevent the onset of colorectal cancer [23]. Consistently with the evaluation of extract effects on colon pro-inflammatory biomarkers, we investigated the bacteriostatic properties of $P$. mahaleb water extract against multiple pathogen bacterial strains, namely Escherichia coli, Pseudomonas aeruginosa, and Staphylococcus aureus, which are involved in ulcerative colitis [24-26]. Finally, considering the very recent interest in studying natural compounds and raw extracts as anti-COVID-19 agents [27-29], in the present study we exposed the human H1299 lung adenocarcinoma cell line to the P. mahaleb extract in order to measure the gene expression of angiotensin-converting enzyme 2 (ACE2) and transmembrane protease serine 2 (TMPRSS2), which are known to play a master role in mediating SARS-CoV-2 virus entry in the human host [30,31]. For convenience, the aims of the present research are schematically summarized in Figure 1, whereas the results support the use of $P$. mahaleb fruits as sources of natural compounds with promising application in treating infectious and inflammatory diseases. 


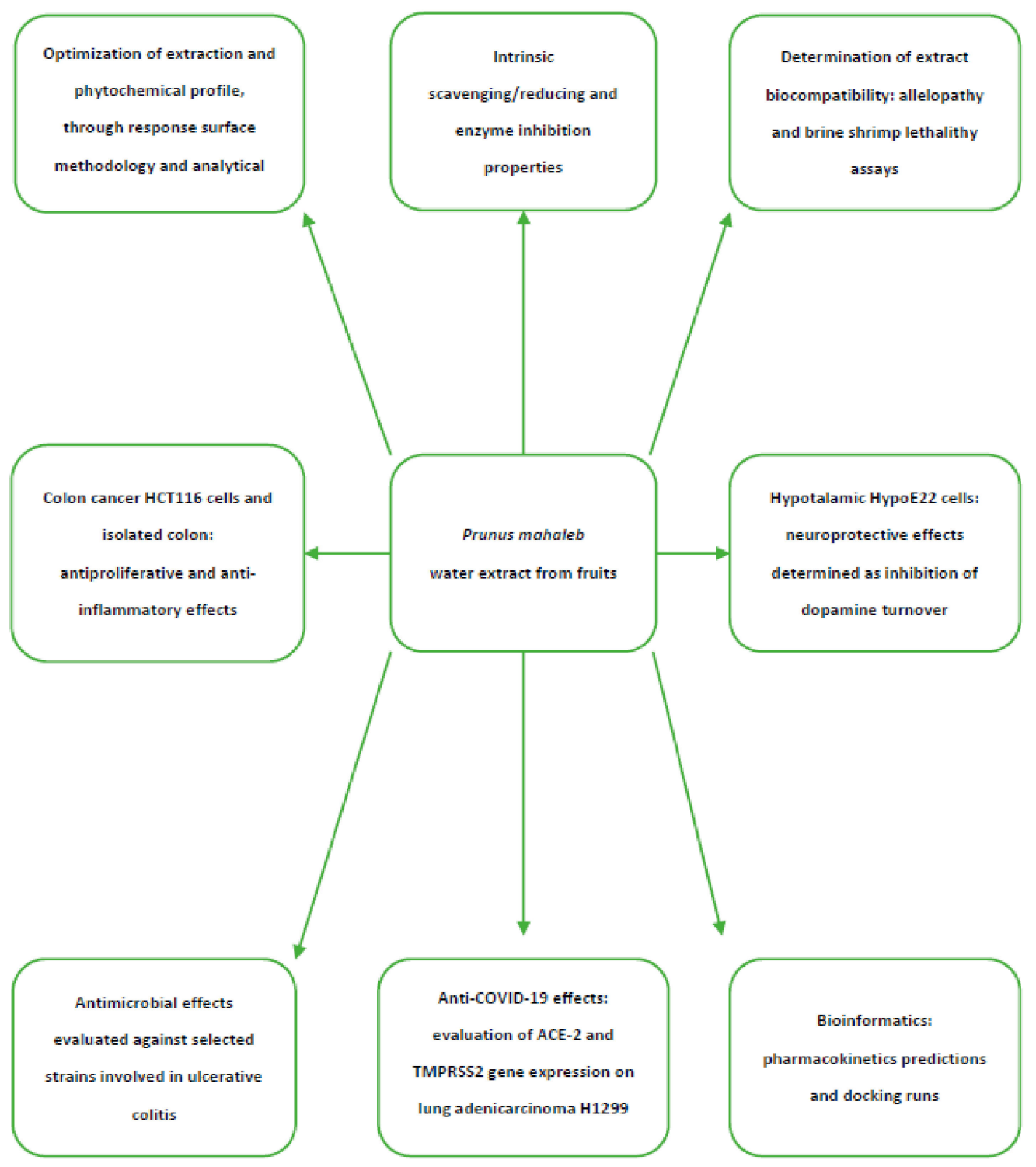

Figure 1. Schematic representation of the aims of the present study.

\section{Results and Discussion}

\subsection{Phytochemical Analysis}

In the present study, the water extract of $P$. mahaleb was analyzed for the determination of phenolic compounds. Specifically, colorimetric assays were carried out for measuring the levels of total phenols, flavonoids, and tannins. The operative conditions for the extractive procedure and experimental data of secondary metabolites quantification are described in paragraph 4.2. The total content of these metabolites in the extract is also consistent with the literature [32] and the scavenging and reducing activities depicted in Table 1. The extract also showed inhibitory effects against different enzymes, namely $\mathrm{AChE}, \mathrm{BChE}$, tyrosinase, $\alpha$-amylase and $\alpha$-glucosidase (Table 2). The $\mathrm{IC}_{50}$ values $(1.28-3.44 \mathrm{mg} / \mathrm{mL}$ ) related to the enzyme inhibition properties are similar to those measured for the investigation of the intrinsic scavenging and reducing properties $(0.97-2.76 \mathrm{mg} / \mathrm{mL})$. This analogy further corroborates previous studies highlighting the tight relationships between antiradical and enzyme inhibition properties [33]. Considering that these enzymes are key targets in the pharmacotherapy of neurodegenerative diseases, type 2 diabetes, and hyperpigmentation [34-36], and all characterized by an increased burden of inflammation and oxidative stress, the present data suggest the rationale for testing the $P$. mahaleb water extract in experimental paradigms simulating these disorders. Furthermore, considering that the observed 
biological properties of the extract are related, albeit partially, to the presence of phenolic compounds [37,38], a quantitative determination of selected phenols and flavonoids was conducted via HPLC-DAD-MS (Figure 2). The chromatographic analysis confirmed the presence of different phytochemicals, namely gallic acid (peak \#2), catechin (peak \#5), chlorogenic acid (peak \#6), epicatechin (peak \#7), caffeic acid (peak \#8), chicoric acid (peak \#9), coumaric acid (peak \#10), ferulic acid (peak \#11) and rutin (peak \#12). Among identified compounds, the prominent were catechins and chicoric acid, which were present in the extract $(20 \mathrm{mg} / \mathrm{mL}$ extract solution) in the concentration range of $2.34-3.00 \mu \mathrm{g} / \mathrm{mL}$, corresponding to $4.74-9.66 \mu \mathrm{M}$. According to docking runs, these compounds may also be responsible, albeit partially, for the enzyme inhibitory effects shown by the extract toward AChE, BChE, tyrosinase, $\alpha$-amylase, and $\alpha$-glucosidase. Specifically, the putative affinities of the aforementioned phenolic compounds against the tested enzymes were in the range of $0.2-8.9 \mu \mathrm{M}$, therefore within the concentration interval shown by chromatographic analysis. Intriguingly, chicoric acid showed sub-micromolar affinity toward cholinesterases, $\alpha$-amylase, and $\alpha$-glucosidase. As depicted in Figure 3, hydrogen bond and pi interactions were mostly responsible for the calculated putative affinities. This compound was also recently identified in the fruit extract of P. spinosa, where its relative amount is comparable to those of catechin and epicatechin [39]. Additionally, other edible plants, including Ocimum basilicum, Lactuca sativa L., Taraxacum officinale, and Cichorium intybus were reported as sources of chicoric acid [40]. Chicoric acid showed multiple promising pharmacological applications, among which are the reduction of the viability of colon cancer HCT116 cells and antimicrobial and neuroprotective effects [41-43]. Regarding the neuroprotective effects, in silico predictions yielded by the bioinformatics platform ADMETPrediction, but also experimental data by Wang and colleagues [44], indicated the capability of chicoric acid to cross the blood brain barrier. Therefore, the inclusion of herbal extracts containing chicoric acid in experimental paradigms aiming to explore neuroprotective effects seems to be rational. Finally, chicoric acid, but also other caffeic acid derivatives, including caftaric acid, were recently described as promising natural compounds for counteracting the COVID-19 pandemic [45]. In this context, the pharmacological study described below focused on unravelling peripheral and central protective effects, antimicrobial, and also anti-COVID-19 properties by the water extract of $P$. mahaleb.

Table 1. Scavenging/reducing properties.

\begin{tabular}{|c|c|c|c|c|c|c|}
\hline Treatments & DPPH & ABTS & CUPRAC & FRAP & Chelating Ability & PBD \\
\hline P. mahaleb water extract & $1.16 \pm 0.01$ & $1.11 \pm 0.03$ & $1.68 \pm 0.09$ & $0.97 \pm 0.05$ & $1.33 \pm 0.04$ & $2.76 \pm 0.09$ \\
\hline $\begin{array}{l}\text { TROLOX } \\
\text { EDTA }\end{array}$ & $\begin{array}{c}0.05 \pm 0.01 \\
\mathrm{nt}\end{array}$ & $\begin{array}{c}0.08 \pm 0.01 \\
\mathrm{nt}\end{array}$ & $\begin{array}{c}0.11 \pm 0.01 \\
\mathrm{nt}\end{array}$ & $\begin{array}{c}0.04 \pm 0.01 \\
\mathrm{nt}\end{array}$ & $\begin{array}{c}\text { nt } \\
0.03 \pm 0.01\end{array}$ & $\begin{array}{c}0.60 \pm 0.02 \\
\text { nt }\end{array}$ \\
\hline
\end{tabular}

nt: not tested. PBD: Phosphomolybdenum. Values are reported as $\mathrm{IC}_{50}(\mathrm{mg} / \mathrm{mL})$.

Table 2. Enzyme inhibition properties.

\begin{tabular}{|c|c|c|c|c|c|}
\hline Treatments & AchE & BChE & Tyrosinase & $\alpha$-Amylase & $\alpha$-Glucosidase \\
\hline P. mahaleb water extract & $1.53 \pm 0.10$ & $1.34 \pm 0.05$ & $1.28 \pm 0.04$ & $3.44 \pm 0.14$ & $1.35 \pm 0.04$ \\
\hline Galantamine & $0.003 \pm 0.0001$ & $0.004 \pm 0.0001$ & nt & nt & nt \\
\hline Kojic acid & nt & nt & $0.08 \pm 0.01$ & nt & nt \\
\hline
\end{tabular}

nt: not tested. Values are reported as $\mathrm{IC}_{50}(\mathrm{mg} / \mathrm{mL})$. 


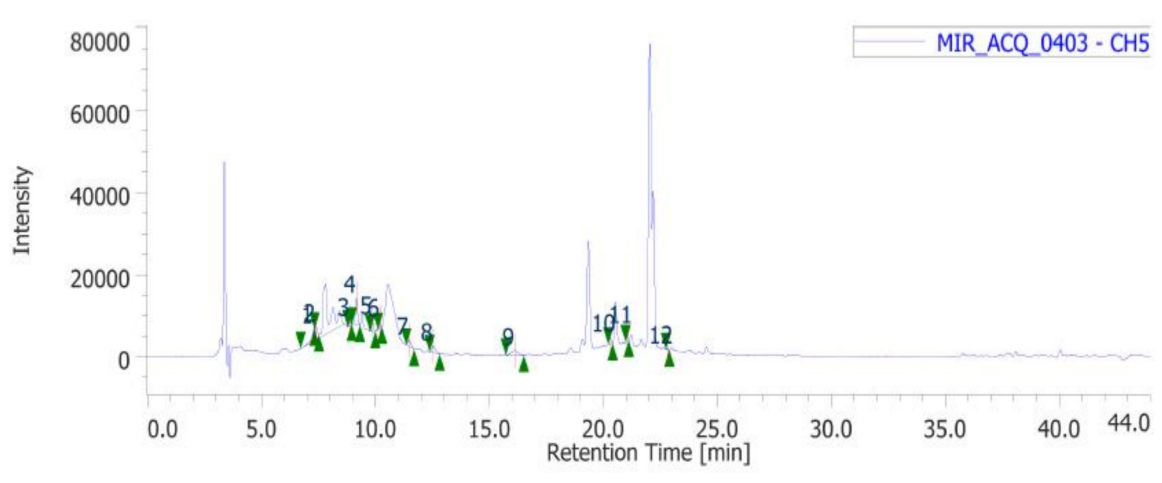

Figure 2. Chromatographic analysis of Prunus mahaleb L. phenolic compounds. The chromatographic analysis confirmed the presence of different phytochemicals, namely gallic acid (peak \#2), catechin (peak \#5), chlorogenic acid (peak \#6), epicatechin (peak \#7), caffeic acid (peak \#8), chicoric acid (peak \#9), coumaric acid (peak \#10), ferulic acid (peak \#11), and rutin (peak \#12).

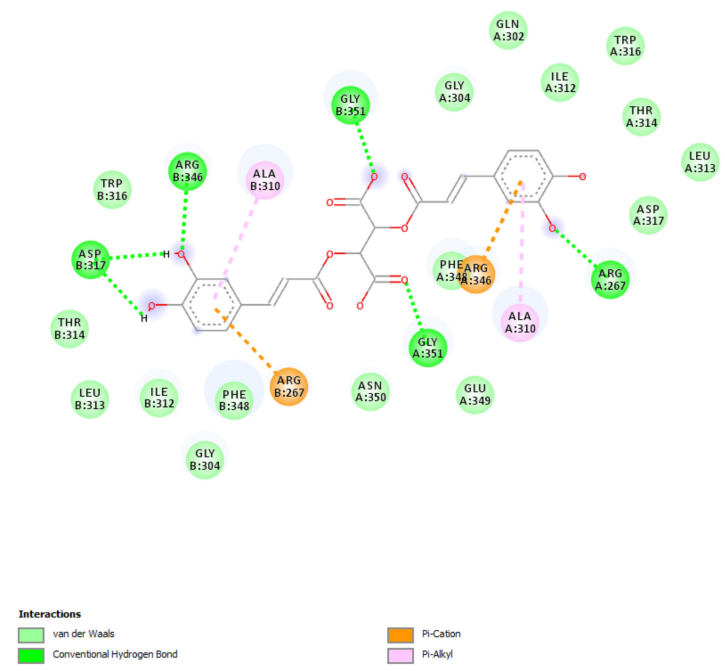

(A)

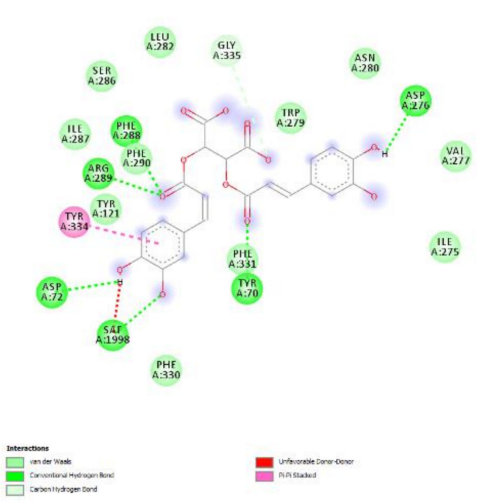

(C)

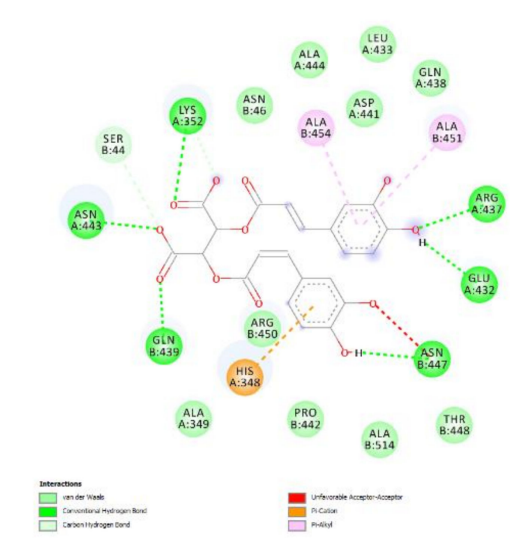

(B)

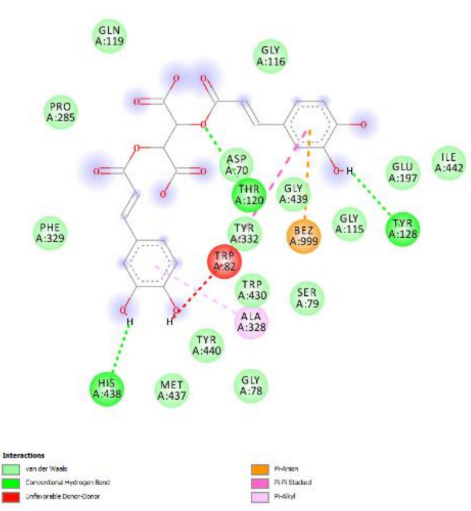

(D)

Figure 3. (A) Putative interactions between chicoric acid and $\alpha$-amylase (PDB: $1 \mathrm{XV} 8$ ). Free energy of binding ( $\Delta \mathrm{G})$ and affinity (Ki) are $-9.2 \mathrm{kcal} / \mathrm{mol}$ and $0.2 \mu \mathrm{M}$, respectively. (B) Putative interactions between chicoric acid and $\alpha$-glucosidase (PDB: 3WY1). Free energy of binding $(\Delta \mathrm{G})$ and affinity $(\mathrm{Ki})$ are $-8.8 \mathrm{kcal} / \mathrm{mol}$ and $0.4 \mu \mathrm{M}$, respectively. (C) Putative interactions between chicoric acid and AChE (PDB: 1GQR). Free energy of binding $(\Delta \mathrm{G})$ and affinity (Ki) are $-8.4 \mathrm{kcal} / \mathrm{mol}$ and $0.7 \mu \mathrm{M}$, respectively. (D) Putative interactions between chicoric acid and BChE (PDB: 1GQR). Free energy of binding $(\Delta \mathrm{G})$ and affinity $(\mathrm{Ki})$ are $-9.5 \mathrm{kcal} / \mathrm{mol}$ and $0.1 \mu \mathrm{M}$, respectively. 


\subsection{Toxicological and Pharmacological Studies}

\subsubsection{Eco-Toxicological Assays}

The biological activity of $P$. mahaleb extract was formerly evaluated through allelopathy assay, a validated pharmacognostic test for discriminating herbal extract phytotoxicity. Particularly, the extract effects on the germination and elongation of the seeds of the lettuce cultivar Lollo bionda were tested in the concentration range $0.1-20 \mathrm{mg} / \mathrm{mL}$. After challenging the seeds with the extract, we did not find any significant alteration on the germination process; however, at the lowest tested concentration we observed a significant root elongation ( $>10 \%$ compared with untreated CTR group: Figure 4$)$. This was considered as a signal of biocompatibility; conversely, a further independent eco-toxicological assay, namely the Artemia salina (brine shrimp) lethality test, was performed for confirming the biocompatibility limits of the water extract. This latter test is widely used, as an alternative toxicological model, for predicting toxicity limits in eukaryotic cells. In this regard, the shrimps nauplii were exposed for $24 \mathrm{~h}$ to the extract $(0.1-20 \mathrm{mg} / \mathrm{mL})$. In agreement with the allelopathy assay, the extract was well-tolerated by the shrimp, with $\mathrm{LC}_{50}$ value > $10 \mathrm{mg} / \mathrm{mL}$ (Figure 5). Considering this result, an extract concentration at least ten-fold lower $(1 \mathrm{mg} / \mathrm{mL})$ was selected for the subsequent pharmacological assays on cell cultures and isolated mouse tissues.

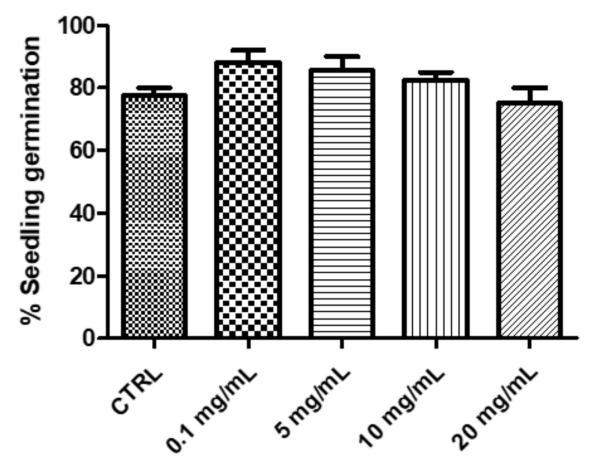

Figure 4. Null effect induced by P. mahaleb $\mathrm{L}$. water extract $(0.1-20 \mathrm{mg} / \mathrm{mL})$ on the seedling germination of the lettuce variety Lollo bionda.

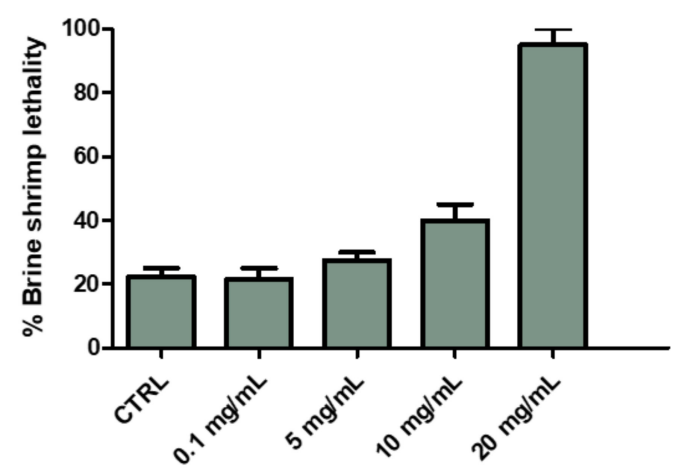

Figure 5. Effect of P. mahaleb L. water extract $(0.1-20 \mathrm{mg} / \mathrm{mL})$ on Artemia salina viability (brine shrimp lethality test).

\subsubsection{Anti-Inflammatory Effects in the Colon and Antimicrobial Properties}

After defining the limits of biocompatibility, the extract $(1000 \mu \mathrm{g} / \mathrm{mL})$ was tested on isolated mouse colon specimens challenged with LPS $(10 \mu \mathrm{g} / \mathrm{mL})$ in order to induce the burden of oxidative stress and inflammation occurring in ulcerative colitis [20,46]. In the present ex vivo experimental model, the extract was able to prevent the gene expression up-regulation of TNF $\alpha$ and COX-2 (Figure 6A,B), thus indicating anti-inflammatory effects in the colon that are consistent with literature data [11]. However, in the study by Ferramosca et al. [11], the evaluation of $P$. mahaleb extract on biochemical pathways 
involved in inflammatory responses was conducted on the liver, and the results were related to the morphological changes in the mouse colon. Therefore, our study is the first to evaluate the direct effects of $P$. mahaleb extract on pro-inflammatory biomarkers in this tissue. Additionally, we also measured the gene expression of HIF1 $\alpha$ and VEGFA, following extract treatment. These proteins are well-known angiogenetic factors deeply involved in the inflammatory to cancer transition in different tissues, including the colon [22] The blunting effects induced by the extract on the LPS-induced gene expression of both (Figure 6C,D) further strengthen the importance of $P$. mahaleb fruits as a source of natural compounds with protective effects in the colon. Considering the inhibition of the gene expression of all tested biomarkers that are not only involved in colon inflammation, but also in tumorigenesis [47-50], we exposed human colon cancer HCT116 cells to scalar concentrations of the extract $(10-1000 \mu \mathrm{g} / \mathrm{mL}$ ) in order to evaluate eventual antiproliferative effects on this colon cancer cell. Unfortunately, the extract did not exert any effect on HCT116 cell viability (Figure 7). Currently, the lack of efficacy as an antiproliferative agent partly agrees with literature data suggesting a good grade of tolerability of isolated cells after exposure to $P$. mahaleb extracts, with $\mathrm{IC}_{50}$ values higher [8] compared to the concentration range employed in the present study. Nevertheless, previous studies [8] did not report the phytochemical composition, thus making a difficult direct comparison with our data. The water extract was also tested for investigating antibacterial effects against pathogen strains involved in ulcerative colitis, namely Escherichia coli, Pseudomonas aeruginosa, and Staphylococcus aureus [24-26]. The antimicrobial assays demonstrated that the water extract of $P$. mahaleb has low antibacterial activity compared to the MIC values of the reference antibacterial drug ciprofloxacin (Table 3). However, the MIC values were in the range of biocompatibility and anti-inflammatory activity showed by the extract; thus, further suggesting its capability in exerting protective effects in the colon, with promising phytotherapy applications in the management of colon inflammatory conditions.
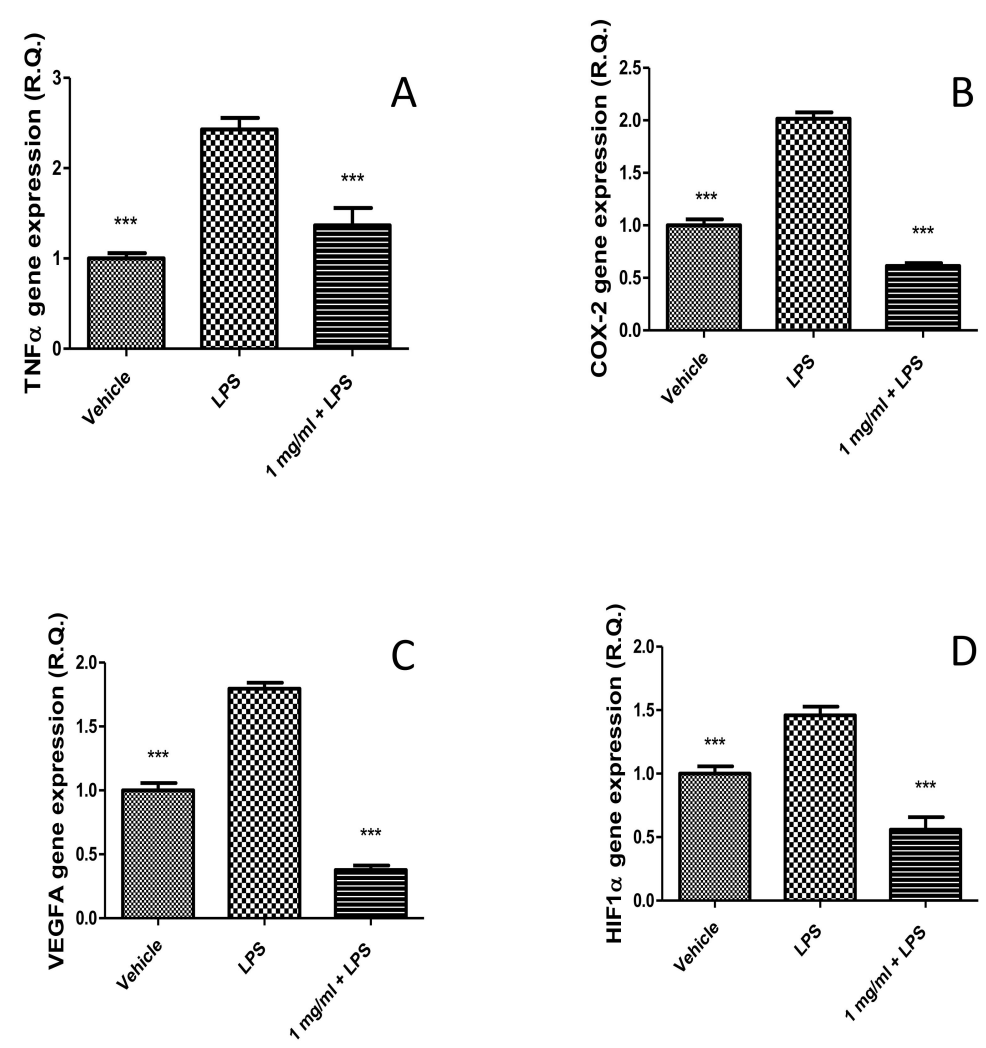

Figure 6. Inhibitory effects induced by Prunus mahaleb L. water extract $(1 \mathrm{mg} / \mathrm{mL})$ on LPS-induced upregulation of TNF $\alpha(\mathbf{A})$, COX-2 (B), VEGFA (C), and HIF1 $\alpha$ (D) gene expression in isolated mouse colon. ANOVA, $p<0.0001 ;{ }^{* * *} p<0.001$ vs. respective LPS group. 


\section{HCT 116}

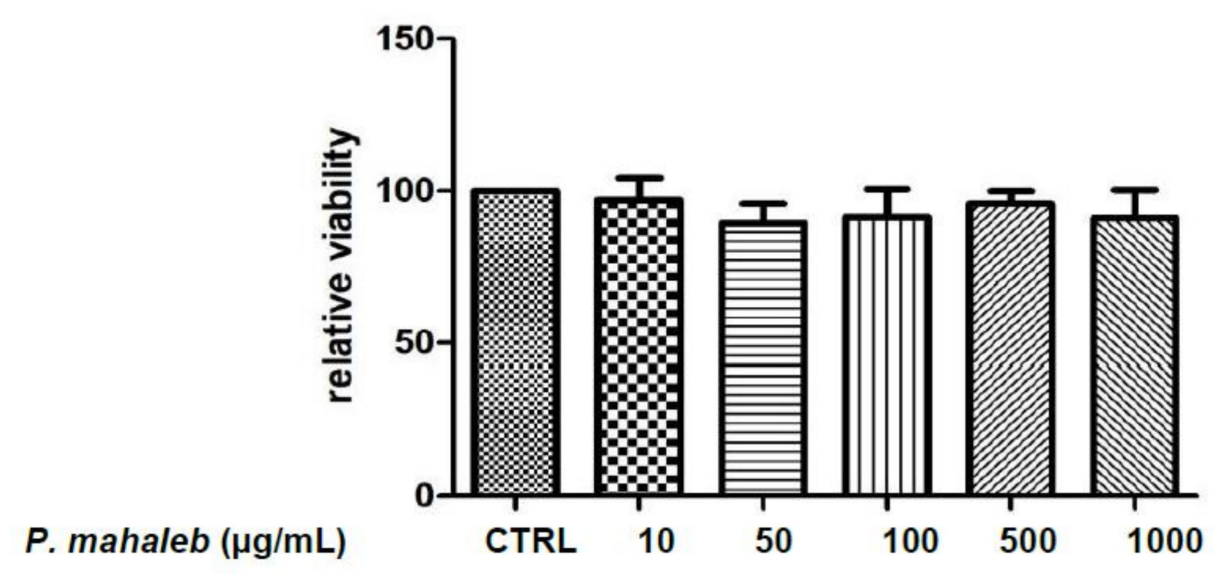

Figure 7. Null effect of Prunus mahaleb L. water extract $(10-1000 \mu \mathrm{g} / \mathrm{mL})$ on human colon cancer HCT116 cell viability.

Table 3. Antibacterial effects by P. mahaleb water extract.

\begin{tabular}{ccc}
\hline Treatments & Bacterial Strains & MIC $(\mu \mathrm{g} / \mathbf{m L})$ \\
\hline P. mahaleb water extract & E. coli (ATCC 10 536) & $31.49(25-50)$ \\
P. mahaleb water extract & P. aeruginosa (ATCC 15442) & $>200$ \\
P. mahaleb water extract & B. cereus (ATCC 12826) & $>200$ \\
Ciprofloxacin & E. coli (ATCC 10536) & $<0.12$ \\
Ciprofloxacin & P. aeruginosa (ATCC 15442) & $1.23(1.95-0.98)$ \\
Ciprofloxacin & B. cereus (ATCC 12826) & $0.62(0.98-0.49)$ \\
\hline
\end{tabular}

\subsubsection{Neuroprotective Effects}

P. mahaleb water extract was also assayed on hypothalamic HypoE22 cells in order to explore potential neuroprotective effects. As shown by the MTT viability test, the extract was well-tolerated by the cell line, with $\%$ cell viability $>70 \%$ at all tested concentrations $(100-1000 \mu \mathrm{g} / \mathrm{mL}$ ) (Figure 8); thus, further confirming the good tolerability profile of the present extract. Additionally, when cells were exposed to the pro-oxidant stimulus constituted by hydrogen peroxide $300 \mu \mathrm{M}$, the extract was effective in preventing the turnover of DA, measured as DOPAC/DA ratio (Figure 9). DOPAC/DA ratio is also a valuable index of monoamine oxidase-B (MAO-B) activity [51], while different herbal extracts were able to prevent brain DA degradation induced by pro-oxidant stimuli $[10,52]$. In the case of the $P$. mahaleb extract, the presence of chicoric acid, with demonstrated capability to cross the blood brain barrier, is sensitive to hypothesize future phytotherapy applications of the P. mahaleb fruit within herbal products to contrast the degradation of DA occurring in Parkinson's disease. In this regard, there is an increasing interest in studying new herbal formulations, including medicinal plants with multiple neuroprotective mechanisms, including the reduction of DA turnover [52-54]. The putative micromolar affinity of the chicoric acid toward MAO-B (Figure 10) is a further stimulus to deepen our knowledge about the neuroprotective effects of this plant that also add not only to the anti-neuroinflammatory effects induced by other Prunus species [16], but also to the capability of the sole chicoric in improving neuron survival and reduced memory impairment in different experimental models of neuroinflammation [42,55]. 


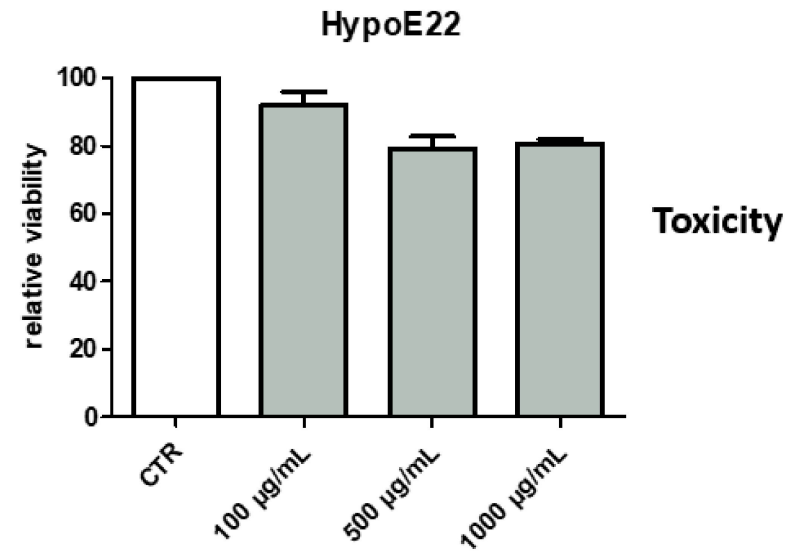

Figure 8. Null effect of Prunus mahaleb L. water extract $(10-1000 \mu \mathrm{g} / \mathrm{mL})$ on hypothalamic HypoE22 cell viability.

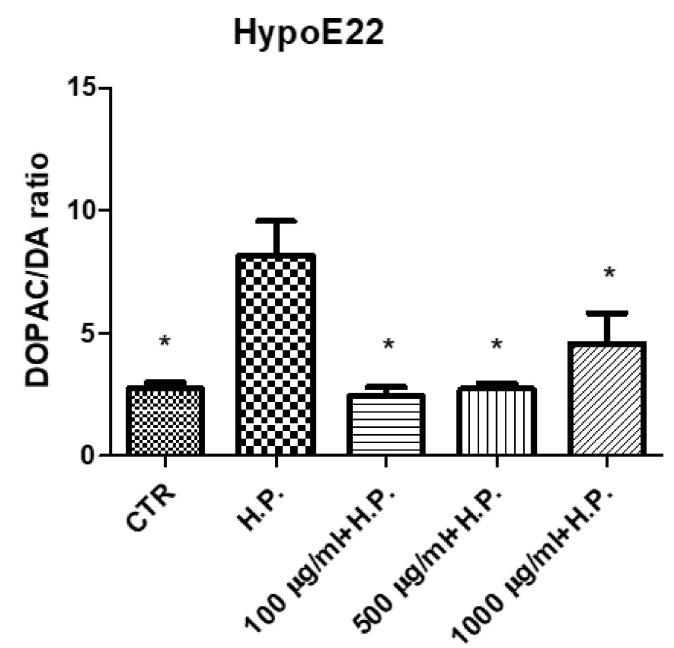

Figure 9. Inhibitory effects induced by Prunus mahaleb L. water extract (100-1000 $\mu \mathrm{g} / \mathrm{mL})$ on hydrogen peroxide (H.P.)-induced DA turnover (DOPAC/DA ratio). ANOVA, $p<0.001$; ${ }^{*} p<0.05$ vs. H.P. group.

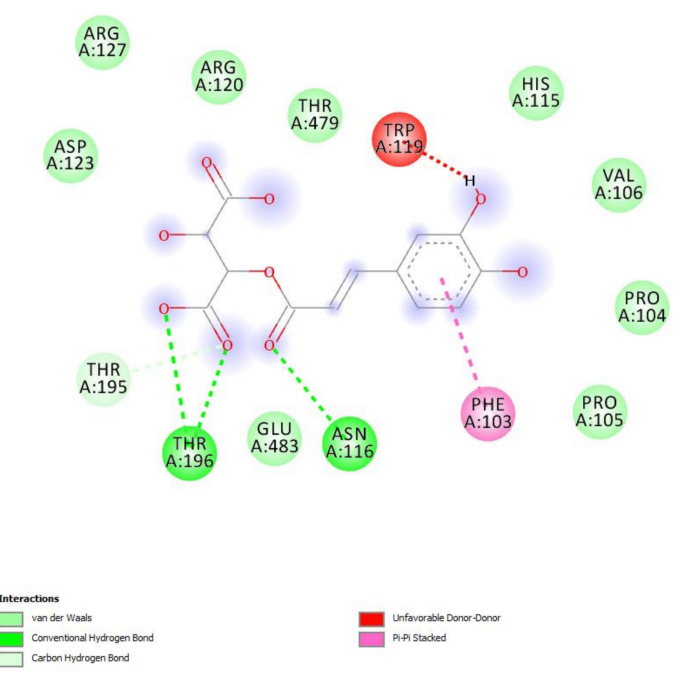

Figure 10. Putative interactions between chicoric acid and MAO-B (PDB: 1GOS). Free energy of binding $(\Delta \mathrm{G})$ and affinity $(\mathrm{Ki})$ are $-7.6 \mathrm{kcal} / \mathrm{mol}$ and $2.3 \mu \mathrm{M}$, respectively. 


\subsubsection{Protective Effects against COVID-19 Infection}

Finally, considering the very recent interest in studying natural compounds and herbal products as anti-COVID-19 agents $[27,28], P$. mahaleb water extract was also investigated in an in vitro model constituted by H1299 lung adenocarcinoma cells, which were reported to express ACE2 and TMPRSS2 [29]. These proteins are deeply involved in mediating SARS-CoV-2 virus entry in the human host $[30,31]$, and the present extract was able to downregulate the gene expression of both proteins at the concentration of $100 \mu \mathrm{g} / \mathrm{mL}$ (Figure 11). Considering the results of the quantitative analysis conducted on the extract, but also the in silico studies carried by Adem and colleagues that pointed to chicoric as promising natural compound for counteracting the COVID-19 pandemic, we also evaluated the affinity of this phytochemical toward ACE2. Regarding this docking approach, we did not consider the putative interactions with TMPRSS2; indeed, the TMPRSS2 structure is not available, and any in silico prediction currently available in the literature [56] are based on hepsin, which is used in view of its homology with TMPRSS2. The results of the docking yielded micromolar affinity of chicoric acid toward ACE2 (Figure 12), thus partly substantiating the pattern of gene expression in $\mathrm{H} 1299$ cells. These promising results support future studies that may be driven with the aim to include the present extract in protecting devices for preventing the SARS-CoV-2 virus entry into the human host.

ACE2

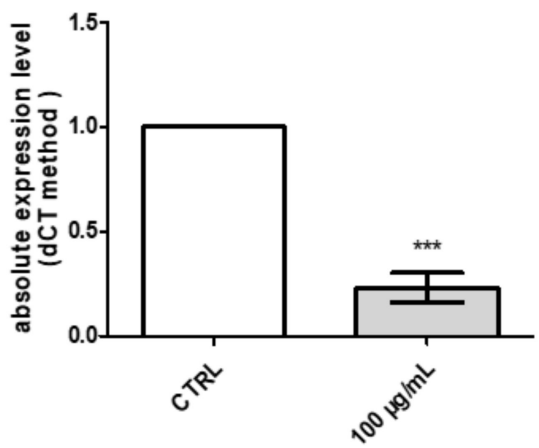

TMPRSS2

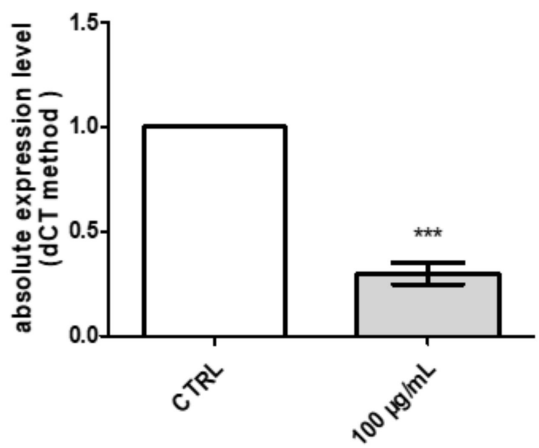

Figure 11. Inhibitory effects induced by Prunus mahaleb L. water extract (100-1000 $\mu \mathrm{g} / \mathrm{mL})$ on ACE2 and TMPRSS2 gene expression in H1299 lung adenocarcinoma cells. ${ }^{* * *} p<0.01$ vs. respective CTR group.
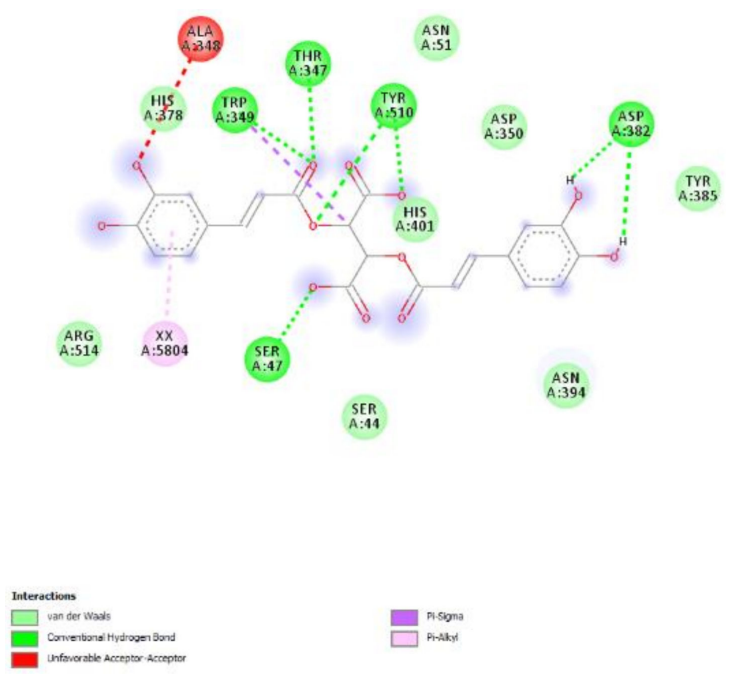

Figure 12. Putative interactions between chicoric acid and ACE2 (PDB: 1R4L). Free energy of binding $(\Delta \mathrm{G})$ and affinity $(\mathrm{Ki})$ are $-7.5 \mathrm{kcal} / \mathrm{mol}$ and $3.2 \mu \mathrm{M}$, respectively. 


\section{Materials and Methods}

\subsection{Plant Material and Reagents}

The plant material consisted of fresh fruits manually collected from Prunus mahaleb L. and cultivated in the surrounding of Torremaggiore (Apulia, Italy). The Prunus plantation was specifically dedicated to collecting fruits for the preparation of the local traditional liqueur called "Mirinello" that is identified as a traditional agrifood product by the Italian Ministry for Agricultural Policies (GU-Serie Generale n. 48 del 26-2-2021 s. ord n 15). It can be considered a modern example of plant domestication. The plant is widely distributed, but for the production of the traditional liqueur, the fruits are collected only from cultivated plants. The origin of this practice is not documented, but still today, for the implementation of plantation, shoots from old samples are collected and grafted on wild P. mahleb rootstock. Fruits at the full ripening stage were manually collected and frozen at $-80^{\circ} \mathrm{C}$ within $6 \mathrm{~h}$. After $24 \mathrm{~h}$, the fruits were stored in plastic sealed bags in the dark at $-20^{\circ} \mathrm{C}$ until used to perform phytochemical and biological assays. Plant identity was confirmed botanically and morphologically by the co-author Prof. Luigi Menghini. The sample used was an aliquot of collection destined to the industrial production of liqueur and was kindly supplied by Mirinello Liquori S.r.l. (Torremaggiore, Apulia, Italy). Phenolic compound standards were purchased from Sigma-Aldrich (Milano, Italy).

\subsection{Response Surface Methodology (RSM)}

The sample of fruits was weighed using a Precisa XT220A balance (Micro Precision Calibration Inc., Grass valley, CA, USA) in $50 \mathrm{~mL}$ Falcon tubes and then immediately homogenized together with the extraction solvent using a T25 digital Ultra-Turrax tissue homogenizer (IKA, Staufen, Germany) for $30 \mathrm{~s}$ at 10,000 g. This treatment partially uniformed the grain size; thus, a better extraction could be performed. Subsequently, ultrasound-assisted water extraction (UAE) of the homogenate was conducted. The sample tube with the mixture was placed in a Trans-sonic T460 ultrasonic bath (Elma, Singen, Germany). The operative conditions for the extraction were optimized through response surface methodology (RSM). A four-factors Box-Behnken design was defined to investigate the effects of parameters such as time, temperature, solid/liquid ratio and percentage of ethanol on UAE of $P$. mahaleb fruits. The effects of independent variables were evaluated as total phenol content (TPC), total flavonoid content (TFC), and total tannin content (TTC). The operative conditions such as extraction method (UAE) were selected on the basis of a previous study [57] while water and ethanol were selected as solvent for extraction due to their food-use compatibility. The range applied for selecting independent variables are detailed in Table 4.

Table 4. Factors and relative extreme level applied to the experimental design.

\begin{tabular}{ccc}
\hline Independent Variables & Levels & \\
\hline & -1 & 1 \\
\hline Time $(\min )$ & 5 & 60 \\
Temperature $\left({ }^{\circ} \mathrm{C}\right)$ & 25 & 80 \\
Ethanol percentage & 0 & 100 \\
Solid $/$ liquid $(\mathrm{g} / \mathrm{mL})$ & 0.010 & 0.10 \\
\hline
\end{tabular}

According to the experimental design, a set of experiments of factorial design at three levels and four factors, with a total of twenty-seven runs, including three replicates at the central point, were applied to evaluate the curvature model, as reported in Table 5. Considering that $P$. mahaleb is traditionally used in the preparation of liqueurs through hydroalcoholic maceration, the RSM also considered the comparison between the water extract and hydroalcoholic solutions. The surface analysis and analysis of variance (ANOVA) to define and optimize the Box-Behnken experimental conditions were conducted with Minitab 16 software. The predicted conditions reported at line 18 of Table 5 permitted to obtain the best results in terms of yield in total phenols (TPC) and total tannins 
(TTC). Specifically, the best conditions for the ultrasound-assisted extraction in water were: time $=32.4 \mathrm{~min} ; \mathrm{TEMP}=52.5^{\circ} \mathrm{C}$; and frequency $=30 \mathrm{kHz}$. Further details about RSM are included as Supplementary Materials.

Table 5. Experimental design matrix with coded variables and experimental data for total polyphenols, total flavonoids, and total tannins.

\begin{tabular}{|c|c|c|c|c|c|c|c|c|c|c|}
\hline \multirow[b]{2}{*}{ Conditions } & \multicolumn{4}{|c|}{ Variables } & \multicolumn{6}{|c|}{ Experimental Results } \\
\hline & Time (min) & Temp $\left({ }^{\circ} \mathrm{C}\right)$ & Ethanol \% & Solid/Liquid (g/mL) & TPC & SD & TFC & SD & TTC & SD \\
\hline 1 & 5 & 52.5 & 50 & 0.01 & 0.198 & 0.035 & 0.044 & 0.001 & 0.184 & 0.005 \\
\hline 2 & 5 & 52.5 & 50 & 0.1 & 0.429 & 0.018 & 0.148 & 0.003 & 0.469 & 0.053 \\
\hline 3 & 60 & 52.5 & 50 & 0.01 & 0.130 & 0.003 & 0.003 & 0.000 & 0.127 & 0.007 \\
\hline 4 & 60 & 52.5 & 50 & 0.1 & 0.658 & 0.023 & 0.197 & 0.006 & 0.591 & 0.032 \\
\hline 5 & 32.5 & 25 & 0 & 0.055 & 0.612 & 0.005 & 0.104 & 0.001 & 0.599 & 0.053 \\
\hline 6 & 32.5 & 25 & 100 & 0.055 & 0.236 & 0.011 & 0.086 & 0.002 & 0.206 & 0.013 \\
\hline 7 & 32.5 & 80 & 0 & 0.055 & 0.648 & 0.082 & 0.096 & 0.002 & 0.645 & 0.048 \\
\hline 8 & 32.5 & 80 & 100 & 0.055 & 0.263 & 0.007 & 0.099 & 0.003 & 0.250 & 0.046 \\
\hline 9 & 32.5 & 25 & 50 & 0.01 & 0.176 & 0.003 & 0.034 & 0.002 & 0.175 & 0.009 \\
\hline 10 & 32.5 & 25 & 50 & 0.1 & 0.447 & 0.013 & 0.119 & 0.001 & 0.437 & 0.024 \\
\hline 11 & 32.5 & 80 & 50 & 0.01 & 0.122 & 0.003 & 0.024 & 0.002 & 0.105 & 0.008 \\
\hline 12 & 32.5 & 80 & 50 & 0.1 & 0.749 & 0.082 & 0.252 & 0.002 & 0.589 & 0.033 \\
\hline 13 & 5 & 52.5 & 0 & 0.055 & 0.568 & 0.011 & 0.099 & 0.001 & 0.587 & 0.060 \\
\hline 14 & 60 & 52.5 & 0 & 0.055 & 0.597 & 0.015 & 0.104 & 0.003 & 0.616 & 0.068 \\
\hline 15 & 5 & 52.5 & 100 & 0.055 & 0.235 & 0.012 & 0.084 & 0.002 & 0.208 & 0.007 \\
\hline 16 & 60 & 52.5 & 100 & 0.055 & 0.243 & 0.002 & 0.084 & 0.002 & 0.182 & 0.006 \\
\hline 17 & 32.5 & 52.5 & 0 & 0.01 & 0.164 & 0.002 & 0.028 & 0.001 & 0.147 & 0.016 \\
\hline 18 & 32.5 & 52.5 & 0 & 0.1 & 0.769 & 0.008 & 0.143 & 0.002 & 0.812 & 0.038 \\
\hline 19 & 32.5 & 52.5 & 100 & 0.01 & 0.078 & 0.005 & 0.019 & 0.001 & 0.105 & 0.034 \\
\hline 20 & 32.5 & 52.5 & 100 & 0.1 & 0.311 & 0.017 & 0.104 & 0.002 & 0.248 & 0.005 \\
\hline 21 & 5 & 25 & 50 & 0.055 & 0.466 & 0.008 & 0.141 & 0.002 & 0.354 & 0.027 \\
\hline 22 & 60 & 25 & 50 & 0.055 & 0.455 & 0.012 & 0.133 & 0.002 & 0.291 & 0.009 \\
\hline 23 & 5 & 80 & 50 & 0.055 & 0.367 & 0.041 & 0.100 & 0.003 & 0.368 & 0.017 \\
\hline 24 & 60 & 80 & 50 & 0.055 & 0.421 & 0.019 & 0.122 & 0.005 & 0.394 & 0.008 \\
\hline 25 & 32.5 & 52.5 & 50 & 0.055 & 0.374 & 0.012 & 0.123 & 0.005 & 0.386 & 0.026 \\
\hline 26 & 32.5 & 52.5 & 50 & 0.055 & 0.531 & 0.016 & 0.161 & 0.001 & 0.332 & 0.012 \\
\hline 27 & 32.5 & 52.5 & 50 & 0.055 & 0.527 & 0.030 & 0.149 & 0.002 & 0.313 & 0.026 \\
\hline
\end{tabular}

Run sequence was conducted randomly. TPC: total polyphenols content expressed as GAE (mg/g); TFC: total flavonoids content expressed as rutin equivalents; TTC: total tannins content expressed as tannic acid equivalents.

\subsection{Scavenging and Reducing and Enzyme Inhibition Properties}

Intrinsic scavenging and reducing properties of the extracts were determined through colorimetric assays [58]. Additionally, extracts were assayed for evaluating enzyme inhibition effects toward tyrosinase, $\alpha$-amylase, $\alpha$-glucosidase, and cholinesterases. Detailed protocols were reported in previous studies [58].

\subsection{Phenolic and Flavonoid Determination: Colorimetric and HPLC-DAD-MS Analyses}

The colorimetric measurement of total phenolic, flavonoid, and tannin levels was conducted according to a recent study [59]. Standards, namely gallic acid (GA) for phenolics, rutin (RU) for flavonoids, and tannic acid for tannins were used to explain the results. The identification and quantification of selected phenolic compounds were conducted through HPLC-DA-MS analysis. The HPLC apparatus consisted of a two PU-2080 PLUS chromato- 
graphic pump, a DG-2080-54 line degasser, a mix-2080-32 mixer, UV, diode array (DAD) and detectors, a mass spectrometer (MS) detector (expression compact mass spectrometer (CMS), Advion, Ithaca, NY 14850, USA), an AS-2057 PLUS autosampler, and a CO-2060 PLUS column thermostat (all from Jasco, Tokyo, Japan). Integration was performed by ChromNAV2 Chromatography software. Before injecting in the HPLC apparatus, the extract was centrifuged at $5000 \mathrm{rpm}$ for $15 \mathrm{~min}$, and supernatant diluted at $10 \mathrm{mg} / \mathrm{mL}$. Water extract $(10 \mathrm{mg} / \mathrm{mL})$ was analyzed for phenol quantitative determination using a reversed-phase HPLC-DAD-MS in gradient elution mode, in agreement with literature data [60]. The separation was conducted within the $32 \mathrm{~min}$ of the chromatographic run, starting from the following separation conditions: $0.1 \%$ formic acid, $95 \%$ water, and $5 \%$ methanol. The separation was performed on an Infinity lab Poroshell 120 reverse phase column $(\mathrm{C} 18,150 \mathrm{~mm} \times 4.6 \mathrm{~mm}$ i.d., $2.7 \mu \mathrm{m})$ (Agilent Santa Clara, CA, USA). Column temperature was set at $30^{\circ} \mathrm{C}$. Quantitative determination of phenolic compounds was performed via DAD detector. The extract was also qualitatively analyzed with MS detector in negative ion mode (vanillic acid, ferulic acid, and naringenin) and positive ion mode (rutin). MS signal identification was realized through comparison with standard solutions and MS spectra present in the MassBank Europe database. The list of compounds analyzed and the wavelengths and the $\mathrm{m} / \mathrm{z}$ ratio for their determination are listed in Table 6. Quantification was done through seven-point calibration curves, with linearity coefficients (R2) > 0.999 , in the concentration range of $2-140 \mu \mathrm{g} / \mathrm{mL}$. The limits of detection were lower than $1 \mu \mathrm{g} / \mathrm{mL}$ for all assayed analytes. The area under the curve from HPLC chromatograms was used to quantify the analyte concentrations in the extract.

Table 6. Wavelengths of quantification and retention times related to the investigated phenolic compounds.

\begin{tabular}{cccc}
\hline Standard & $m / z$ & Wavelengths (nm) & Retention Time (min) \\
\hline Gallic acid & 169.1 & 254 & 7.303 \\
\hline Catechin & 289.3 & 254 & 9.867 \\
\hline Chlorogenic acid & 353.31 & 254 & 10.203 \\
\hline Epicatechin & 289.3 & 254 & 11.473 \\
\hline Caffeic acid & 179.16 & 254 & 12.533 \\
\hline Chicoric acid & 473.37 & 254 & 16.117 \\
\hline Coumaric acid & 163.04 & 254 & 20.293 \\
\hline Ferulic acid & 193.1 & 254 & 21.033 \\
\hline Rutin & 611.5 & 254 & 22.813 \\
\hline
\end{tabular}

\subsection{Eco-Toxicological Profile: Allelopathy and Artemia salina (brine shrimp) Lethality Assays}

Allelopathy bioassay was carried on the seeds of the commercial lettuce variety Lollo bionda because of its fast germination rate and high sensitivity. The detailed procedure was conducted as previously reported [10]. Seeds were treated with scalar $P$. mahaleb extract concentrations $(0.1-20 \mathrm{mg} / \mathrm{mL})$ and considered germinated for observed root length $\geq 1$ $\mathrm{mm}$, after the third day of treatment. Artemia salina cysts were cultivated in oxygenated artificial sea water ( $1 \mathrm{~g}$ cysts/L). After $24 \mathrm{~h}$, brine shrimp larvae were gently transferred with a pipette in 6 well plates containing $2 \mathrm{~mL}$ of the extract at different concentrations $(0.1-20 \mathrm{mg} / \mathrm{mL})$ in artificial sea water. The detailed protocol is reported in our previous paper [10].

\subsection{Human Colon Cancer HCT116 Cells: Evaluation of Antiproliferative Effects}

Human colon cancer-derived HCT116 cells were cultured in DMEM (Euroclone) supplemented with $10 \%(v / v)$ heat-inactivated fetal bovine serum and $1.2 \%(v / v)$ penicillin $\mathrm{G} /$ streptomycin in a $75 \mathrm{~cm} 2$ tissue culture flask ( $\mathrm{n}=5$ for individual culture flasks for each condition). The cultured cells were maintained in a humidified incubator with $5 \% \mathrm{CO}_{2}$ at 
$37^{\circ} \mathrm{C}$. For cell differentiation, HCT116 cell suspension at a density of $1 \times 106$ cells $/ \mathrm{mL}$ was treated with various concentrations $(10,50$, and $100 \mathrm{ng} / \mathrm{mL})$ of phorbol myristate acetate (PMA, Fluka) for $24 \mathrm{~h}$ or $48 \mathrm{~h}$ (induction phase). Thereafter, the PMA-treated cells were washed twice with ice-cold pH 7.4 phosphate buffer solution (PBS) to remove PMA and nonadherent cells, whereas the adherent cells were further maintained for $48 \mathrm{~h}$ (recovery phase). Morphology of cells was examined under an inverted phase-contrast microscope. To assess the basal cytotoxicity of water extract, a viability test was performed on 96 microwell plates, using 3-(4,5-dimethylthiazol-2-yl)-2,5-diphenyltetrazolium bromide (MTT) test. Cells were incubated with extracts (ranging in the concentration 10-1000 $\mu \mathrm{g} / \mathrm{mL}$ ) for $24 \mathrm{~h}$. A total of $10 \mu \mathrm{L}$ of MTT $(5 \mathrm{mg} / \mathrm{mL})$ was added to each well and incubated for $3 \mathrm{~h}$. The formazan dye formed was extracted with dimethyl sulfoxide and absorbance was recorded as previously described [38]. Effects on cell viability were evaluated in comparison to the untreated control group.

\subsection{Isolated Mouse Colon Specimens: Evaluation of Anti-Inflammatory Effects}

Fifteen male adult mice were housed in plexiglass cages $(40 \mathrm{~cm} \times 25 \mathrm{~cm} \times 15 \mathrm{~cm})$, two rats per cage, in climatized colony rooms $\left(22 \pm 1{ }^{\circ} \mathrm{C} ; 60 \%\right.$ humidity), on a $12 \mathrm{~h} / 12 \mathrm{~h}$ light/dark cycle (light phase: 07:00-19:00 h), with free access to tap water and food, $24 \mathrm{~h} /$ day throughout the study, with no fasting periods. Mice were fed a standard laboratory diet $3.5 \%$ fat, $63 \%$ carbohydrate, $14 \%$ protein, $19.5 \%$ other components without caloric value; $3.20 \mathrm{kcal} / \mathrm{g}$ ). Housing conditions and experimentation procedures were strictly in accordance with the European Union ethical regulations on the care of animals for scientific research. According to the recognized ethical principles of "Replacement, Refinement and Reduction of Animals in Research", colon specimens were obtained as residual material from vehicle-treated rats randomized in our previous experiments and approved by a local ethical committee (University "G. d'Annunzio" of Chieti-Pescara) and the Italian Health Ministry (Italian Health Ministry authorization N. F4738.N.5QP). Mice were sacrificed by $\mathrm{CO}_{2}$ inhalation $\left(100 \% \mathrm{CO}_{2}\right.$ at a flow rate of $20 \%$ of the chamber volume per min) and colon specimens were immediately collected and maintained in a humidified incubator with $5 \%$ $\mathrm{CO}_{2}$ at $37^{\circ} \mathrm{C}$ for $4 \mathrm{~h}$, in RPMI buffer with added bacterial LPS (10 $\mu \mathrm{g} / \mathrm{mL}$ ) (incubation period). During the incubation period, tissues were treated with the sub-toxic concentration of water extract $(1000 \mu \mathrm{g} / \mathrm{mL})$. Tissue specimens and supernatants were collected for gene expression and chromatographic analyses, respectively, of pro-inflammatory biomarkers, as detailed below.

\subsection{Hypothalamic HypoE22 Cells: Evaluation of Neuroprotective Effects}

HypoE22 cells were purchased from Cedarlane Cellution Biosystem and cultured in DMEM (Euroclone) supplemented with $10 \%(v / v)$ heat-inactivated fetal bovine serum and $1.2 \%(v / v)$ penicillin $\mathrm{G} /$ streptomycin in a $75 \mathrm{~cm}^{2}$ tissue culture flask $(n=5$ individual culture flasks for each condition). The culture conditions and the viability 3-(4,5dimethylthiazol-2-yl)-2,5-diphenyltetrazolium bromide (MTT) test were performed as previously described [9]. Effects of the extract $(100-1000 \mu \mathrm{g} / \mathrm{mL})$ on cell viability were evaluated in comparison to the untreated control group, constituted by either vehicle or hydrogen peroxide (H.P.) $300 \mu \mathrm{M}$ stimulus.

\subsection{Human H1299 Lung Adenocarcinoma Cell Line: Anti-COVID-19 Effects}

The human H1299 lung adenocarcinoma cell line was cultured with an RMPI-16140 medium supplemented with $10 \%$ heat-inactivated fetal bovine serum, $100 \mathrm{U} / \mathrm{mL}$ penicillin, and $100 \mu \mathrm{g} / \mathrm{mL}$ streptomycin. Cells were incubated at $37{ }^{\circ} \mathrm{C}$ with $5 \% \mathrm{CO}_{2}$. The H1299 cell line was purchased from ATCC (Manassas, VA, United States). In the experiments, cells were seeded into six well culture plates, kept ad concentration of $2 \times 10^{5}$ cells $/ \mathrm{mL}$, and after $24 \mathrm{~h}$, were treated with different concentrations of the extract (500-1000 $\mu \mathrm{g} / \mathrm{mL})$ for $24 \mathrm{~h}$. After cell stimulation, total mRNA was extracted for the evaluation of ACE2 and TMPRSS2 gene expression. 


\subsection{Gene Expression Analysis}

Gene expression of TNF $\alpha$, COX-2, VEGF, HIF1 $\alpha$, ACE2, and TMPRSS2 was conducted as previously reported [60]. Briefly, after extraction through the TRI Reagent, total RNA was reverse transcribed using High Capacity cDNA Reverse Transcription Kit (ThermoFischer Scientific, Waltman, Massachusetts, USA). Gene expression was determined by quantitative real-time PCR using TaqMan probes obtained from ThermoFischer Scientific (Waltman, Massachusetts, USA). $\beta$-actin was used as the housekeeping gene. The analysis of data was conducted with the Sequence Detection System (SDS) software version 2.3 (ThermoFischer Scientific, Waltman, Massachusetts, USA). A detailed description of the experimental protocol is reported in a previous paper of ours [20].

\subsection{Quantitative Determination of Dopamine (DA), Dihydroxyphenilacetic Acid (DOPAC)}

DA and DOPAC levels were analyzed through an HPLC apparatus consisting of a Jasco (Tokyo, Japan) PU-2080 chromatographic pump and an ESA (Chelmsford, MA, USA) Coulochem III coulometric detector, equipped with a microdialysis cell (ESA-5014b) porous graphite working electrode and solid state palladium reference electrode. The detailed description of the chromatographic analysis is fully described in our previous study [61].

\subsection{Antibacterial Effects}

In vitro antimicrobial effects of the water extract from P. mahaleb were assessed against three bacterial strains (CLSI M07-A9), namely E. coli (ATCC 10536), P. aeruginosa (ATCC 15442), and S. aureus (ATCC 6538). Detailed description of the experimental protocol is reported in our recent paper, [62].

\subsection{Bioinformatics}

In silico pharmacokinetics evaluations were conducted on the platforms SwissAdmePrediction and ADMETPrediction. Docking calculations were conducted through the Autodock Vina of PyRx 0.8 software, as recently described [63]. Crystal structures of target proteins were derived from the Protein Data Bank (PDB) with PDB ID as follows: 1R4L (inhibitor-bound human angiotensin-converting enzyme-related carboxypeptidase: ACE2), 513B (Tyrosinase), 1XV8 ( $\alpha$-amylase), 3WY1 ( $\alpha$-glucosidase), 1GQR (acethylcholinesterase: AchE), 309M (Butyrylcholinesterase: BChE), and 1GOS (Monoaminoxidase-B: MAO-B). Discovery studio 2020 visualizer was employed to investigate the protein-ligand nonbonding interactions.

\subsection{Statistical Analysis}

The experimental data related to in vitro and ex vivo studies were analyzed through the analysis of variance (ANOVA) followed by Newman-Keuls post hoc test. The GraphPad Prism software was employed for statistical analysis. $p<0.05$ was considered statistically significant. The number of animals to be employed in the study was calculated using G*Power software (v3.1.9.4, University of Kiel, Kiel, Germany). The values of the study potency $(1-\beta)$ and the significance level $(\alpha)$ were 0.8 and 0.05 , respectively.

\section{Conclusions}

In conclusion, the present study explored the health potential of the water extract from the fruit of $P$. mahaleb, a wild edible plant that has been used for centuries in the liqueur tradition. The study explored the phytochemical composition in phenolic compounds, finding significant amounts of catechin and chicoric acid that may explain, albeit partially, the observed pharmacological properties, in terms of protective effects against inflammatory and infectious diseases. In this regard, the bacteriostatic effects induced on Gram+ and Gram- strains, together with the inhibition of COX-2, TNF $\alpha, \mathrm{HIF} 1 \alpha$, and VEGFA suggest the potential of $P$. mahaleb water extract in contrasting the clinical symptoms related to ulcerative colitis. The inhibition of hydrogen peroxide-induced DOPAC/DA ratio, in hypothalamic neurons, indicates promising neuroprotective effects. In view of future in vivo 
studies to confirm this finding, it is sensitive to highlight the capability of chicoric acid to cross the blood brain barrier and its putative affinity toward MAO-B, which is deeply involved in DA turnover. Finally, but not for importance, there is the ability of the extract to downregulate the gene expression of ACE2 and TMPRSS2 in human adenocarcinoma H1299 cells. As ACE2 and TMPRSS2 are involved in SARS-CoV-2 virus entry in the human host, with the present findings, we hypothesize the inclusion of the present extract in protection devices, such as surgical masks, functioning as physical barriers against COVID-19. Overall, the results of this research point to the valorization of the local cultivation of P. mahaleb, an ancient botanical resource with promising health perspectives.

Supplementary Materials: Supplementary material are available online.

Author Contributions: Conceptualization, G.O., C.F., L.M., D.V.D., A.M., G.Z. and L.B.; methodology, C.F. and L.M.; software, L.M. and C.F.; validation, C.F., L.M. and G.O.; formal analysis, C.F. and G.Z.; investigation, S.A., A.C., S.C.D.S., F.D.C., L.R., S.L., A.A., P.A., G.A.F. and R.V.; resources, G.O., L.M. and C.F.; data curation, C.F., G.O. and L.M.; writing-original draft preparation, C.F., writing-review and editing, C.F., G.O., L.M. and A.M.; visualization, L.B.; G.Z., A.M., D.V.D., P.A. and R.V.; supervision, L.B.; project administration, L.M., G.O. and C.F.; funding acquisition, G.O., C.F. and L.M. All authors have read and agreed to the published version of the manuscript.

Funding: The study was supported by funds from Cristalfarma S.r.l. within the joint project entitled: "Il Giardino dei Semplici e lo studio della biodiversità vegetale come modello per la valorizzazione delle filiere sostenibili". Coordinators of the study are Luigi Menghini, Giustino Orlando and Claudio Ferrante.

Institutional Review Board Statement: Animal experimental procedures were approved by the local ethical committee (University "G. d'Annunzio" of Chieti-Pescara) and Italian Health Ministry (Italian Health Ministry authorization N. F4738.N.5QP).

Informed Consent Statement: Not applicable.

Data Availability Statement: Not applicable.

Acknowledgments: The study was supported by funds from Cristalfarma S.r.l. within the joint project entitled, "Il Giardino dei Semplici e lo studio della biodiversità vegetale come modello per la valorizzazione delle filiere sostenibili". Coordinators of the study were Luigi Menghini, Giustino Orlando, and Claudio Ferrante. The present article is also part of the third mission activities of the Botanic Garden "Giardino dei Semplici" planned for the 20th anniversary of the establishment.

Conflicts of Interest: The authors declare no conflict of interest.

Sample Availability: Samples of the compounds are not available from the authors.

\section{References}

1. Chen, X.; Shen, X.; Jiang, D. Complete chloroplast genome sequence of Prunus mahaleb. Mitochondrial DNA Part B 2019, 4, 2204-2205. [CrossRef]

2. Palasciano, M.; Ferrara, G.; Camposeo, S.; Laghezza, L. Studies on Prunus mahaleb in Apulia. Ital. J. Agron. 2009,4 , 705-708.

3. Blando, F.; Albano, C.; Liu, Y.; Nicoletti, I.; Corradini, D.; Tommasi, N.; Gerardi, C.; Mita, G.; Kitts, D.D. Polyphenolic composition and antioxidant activity of the under-utilised Prunus mahaleb L. fruit. J. Sci. Food Agric. 2016, 96, 2641-2649. [CrossRef] [PubMed]

4. Mariod, A.A.; Ibrahim, R.M.; Ismail, M.; Ismail, N. Antioxidant activities of phenolic rich fractions (PRFs) obtained from black mahlab (Monechma ciliatum) and white mahlab (Prunus mahaleb) seedcakes. Food Chem. 2010, 118, 120-127. [CrossRef]

5. Al-Said, M.S.; Hifnawy, M.S. Dihydrocoumarin and certain other coumarins from Prunus mahaleb seeds. J. Nat. Prod. 1986, 49, 721. [CrossRef]

6. Ieri, F.; Pinelli, P.; Romani, A. Simultaneous determination of anthocyanins, coumarins and phenolic acids in fruits, kernels and liqueur of Prunus mahaleb L. Food Chem. 2012, 135, 2157-2162. [CrossRef] [PubMed]

7. Akbari, F.; Dashti, A.; Vahedi, L.; Davoodi, A. Effect of Prunus mahaleb L. Seed Extract on Ethylene glycol-and Ammonium Chloride-Induced Urolithiasis in BALB/c Mice. Iran. J. Med. Sci. 2020, 45, 134. [PubMed]

8. Abudayyak, M.; Nath, E.Ö.; Özhan, G. Toxic potentials of ten herbs commonly used for aphrodisiac effect in Turkey. Turk. J. Med. Sci. 2015, 45, 496-506. [CrossRef]

9. di Giacomo, V.; Ferrante, C.; Ronci, M.; Cataldi, A.; Di Valerio, V.; Rapino, M.; Recinella, L.; Chiavaroli, A.; Leone, S.; VladimirKnežević, S.; et al. Multiple pharmacological and toxicological investigations on Tanacetum parthenium and Salix alba extracts: Focus on potential application as anti-migraine agents. Food Chem. Toxicol. 2019, 133, 110783. [CrossRef] 
10. Ferrante, C.; Recinella, L.; Ronci, M.; Menghini, L.; Brunetti, L.; Chiavaroli, A.; Leone, S.; Di Iorio, L.; Carradori, S.; Tirillini, B.; et al. Multiple pharmacognostic characterization on hemp commercial cultivars: Focus on inflorescence water extract activity. Food Chem. Toxicol. 2019, 125, 452-461. [CrossRef]

11. Ferramosca, A.; Treppiccione, L.; Di Giacomo, M.; Aufiero, V.R.; Mazzarella, G.; Maurano, F.; Gerardi, C.; Rossi, M.; Zara, V.; Mita, G.; et al. Prunus Mahaleb Fruit Extract Prevents Chemically Induced Colitis and Enhances Mitochondrial Oxidative Metabolism via the Activation of the Nrf2 Pathway. Mol. Nutr. Food Res. 2019, 63, 1900350. [CrossRef]

12. Truong, V.L.; Jun, M.; Jeong, W.S. Role of resveratrol in regulation of cellular defense systems against oxidative stress. Biofactors 2018, 44, 36-49. [CrossRef]

13. Ben Lagha, A.; LeBel, G.; Grenier, D. Tart cherry (Prunus cerasus L.) fractions inhibit biofilm formation and adherence properties of oral pathogens and enhance oral epithelial barrier function. Phytother. Res. 2020, 34, 886-895. [CrossRef]

14. Reddy, M.K.; Alexander-Lindo, R.L.; Nair, M.G. Relative inhibition of lipid peroxidation, cyclooxygenase enzymes, and human tumor cell proliferation by natural food colors. J. Agric. Food Chem. 2005, 53, 9268-9273. [CrossRef]

15. Šarić, A.; Sobočanec, S.; Balog, T.; Kušić, B.; Šverko, V.; Dragović-Uzelac, V.; Levaj, B.; Čosić, Z.; Šafranko, Ž.M.; Marotti, T. Improved antioxidant and anti-inflammatory potential in mice consuming sour cherry juice (Prunus Cerasus cv. Maraska). Plant Foods Hum. Nutr. 2009, 64, 231-237. [CrossRef]

16. Bonaventura, M.V.M.D.; Martinelli, I.; Moruzzi, M.; Bonaventura, E.M.D.; Giusepponi, M.E.; Polidori, C.; Lupidi, G.; Tayebati, S.K.; Amenta, F.; Cifani, C.; et al. Brain alterations in high fat diet induced obesity: Effects of tart cherry seeds and juice. Nutrients 2020, 12, 623. [CrossRef]

17. Ibars, M.; Aragonès, G.; Ardid-Ruiz, A.; Gibert-Ramos, A.; Arola-Arnal, A.; Suárez, M.; Bladé, C. Seasonal consumption of polyphenol-rich fruits affects the hypothalamic leptin signaling system in a photoperiod-dependent mode. Sci. Rep. 2018, 8, 1-13. [CrossRef] [PubMed]

18. Ferrante, C.; Chiavaroli, A.; Angelini, P.; Venanzoni, R.; Angeles Flores, G.; Brunetti, L.; Petrucci, M.; Politi, M.; Menghini, L.; Leone, S.; et al. Phenolic Content and Antimicrobial and Anti-Inflammatory Effects of Solidago virga-aurea, Phyllanthus niruri, Epilobium angustifolium, Peumus boldus, and Ononis spinosa Extracts. Antibiotics 2020, 9, 783. [CrossRef] [PubMed]

19. Sinan, K.I.; Chiavaroli, A.; Orlando, G.; Bene, K.; Zengin, G.; Cziáky, Z.; Jekő, J.; Mahomoodally, M.F.; Picot-Allain, M.C.N.; Menghini, L.; et al. Evaluation of Pharmacological and Phytochemical Profiles Piptadeniastrum africanum (Hook. f.) Brenan Stem Bark Extracts. Biomolecules 2020, 10, 516. [CrossRef] [PubMed]

20. Menghini, L.; Ferrante, C.; Leporini, L.; Recinella, L.; Chiavaroli, A.; Leone, S.; Pintore, G.; Vacca, M.; Orlando, G.; Brunetti, L. An hydroalcoholic chamomile extract modulates inflammatory and immune response in HT29 cells and isolated rat colon. Phytother. Res. 2016, 30, 1513-1518. [CrossRef] [PubMed]

21. Bouguen, G.; Chevaux, J.-B.; Peyrin-Biroulet, L. Recent advances in cytokines: Therapeutic implications for inflammatory bowel diseases. World J. Gastroenterol. 2011, 17, 547. [CrossRef]

22. Chen, X.; Xu, C.; Hong, S.; Xia, X.; Cao, Y.; McDermott, J.; Mu, Y.; Han, J.-D.J. Immune cell types and secreted factors contributing to inflammation-to-cancer transition and immune therapy response. Cell Rep. 2019, 26, 1965-1977. [CrossRef]

23. Gavrilaş, L.I.; Ionescu, C.; Bălăcescu, O.; Muresan, D.; Revnic, C.; Filip, L.; Miere, D. Intake of plant based foods and colorectal cancer. A case-control study in Romania. Bull. UASVM Food Sci. Technol. 2018, 75, 2. [CrossRef]

24. Iguidbashian, J.P.; Parekh, J.D.; Kukrety, S.; Andukuri, V.G. Campylobacter jejuni and Pseudomonas coinfection in the setting of ulcerative colitis. Case Rep. 2018, 2018, bcr2018224941.

25. Sünderhauf, A.; Pagel, R.; Künstner, A.; Wagner, A.E.; Rupp, J.; Ibrahim, S.M.; Derer, S.; Sina, C. Saccharin supplementation inhibits bacterial growth and reduces experimental colitis in mice. Nutrients 2020, 12, 1122. [CrossRef] [PubMed]

26. Tripathi, M.K.; Pratap, C.B.; Dixit, V.K.; Singh, T.B.; Shukla, S.K.; Jain, A.K.; Nath, G. Ulcerative colitis and its association with salmonella species. Interdiscip. Persp. Infect. Dis. 2016, 2016, 5854285.

27. Anil, S.M.; Shalev, N.; Vinayaka, A.C.; Nadarajan, S.; Namdar, D.; Belausov, E.; Shoval, I.; Mani, K.A.; Mechrez, G.; Koltai, H. Cannabis compounds exhibit anti-inflammatory activity in vitro in COVID-19-related inflammation in lung epithelial cells and pro-inflammatory activity in macrophages. Sci. Rep. 2021, 11, 1-14. [CrossRef] [PubMed]

28. Mahrosh, H.S.; Mustafa, G. An in silico approach to target RNA-dependent RNA polymerase of COVID-19 with naturally occurring phytochemicals. Environ. Dev. Sustain. 2021, 1-14.

29. Orlando, G.; Adorisio, S.; Delfino, D.; Chiavaroli, A.; Brunetti, L.; Recinella, L.; Leone, S.; D'Antonio, M.; Zengin, G.; Acquaviva, A.; et al. Comparative investigation of composition, antifungal, and anti-inflammatory effects of the essential oil from three industrial hemp varieties from Italian cultivation. Antibiotics 2021, 10, 334. [CrossRef]

30. Sungnak, W.; Huang, N.; Bécavin, C.; Berg, M.; Queen, R.; Litvinukova, M.; Talavera-López, C.; Maatz, H.; Reichart, D.; Sampaziotis, F.; et al. SARS-CoV-2 entry factors are highly expressed in nasal epithelial cells together with innate immune genes. Nat. Med. 2020, 26, 681-687. [CrossRef]

31. Turner, A.J.; Hiscox, J.A.; Hooper, N.M. ACE2: From vasopeptidase to SARS virus receptor. Trends Pharmacol. Sci. 2004, 25, 291-294. [CrossRef] [PubMed]

32. Bazrafkan, F.; Zarringhalami, S.; Ganjloo, A. Response surface optimization of conditions for debittering of white mahlab (Prunus mahaleb L.) juice using polystyrene resins. Food Sci. Biotechnol. 2017, 26, 1555-1562. [CrossRef] [PubMed] 
33. Chatatikun, M.; Supjaroen, P.; Promlat, P.; Chantarangkul, C.; Waranuntakul, S.; Nawarat, J.; Tangpong, J. Antioxidant and Tyrosinase Inhibitory Properties of an Aqueous Extract of Garcinia atroviridis Griff. ex. T. Anderson Fruit Pericarps. Pharmacogn. J. 2020, 12, 71-78. [CrossRef]

34. Dorababu, A. Critical evaluation of current Alzheimer's drug discovery (2018-19) \& futuristic Alzheimer drug model approach. Bioorg. Chem. 2019, 93, 103299.

35. Saeedi, M.; Eslamifar, M.; Khezri, K. Kojic acid applications in cosmetic and pharmaceutical preparations. Biomed. Pharmacother. 2019, 110, 582-593. [CrossRef]

36. Wu, L.; Wu, W.; Cai, Y.; Li, C.; Wang, L. HPLC fingerprinting-based multivariate analysis of phenolic compounds in mango leaves varieties: Correlation to their antioxidant activity and in silico $\alpha$-glucoidase inhibitory ability. J. Pharm. Biomed. Anal. 2020, 191, 113616. [CrossRef] [PubMed]

37. Martinez-Gonzalez, A.I.; Díaz-Sánchez, Á.G.; Rosa, L.A.; Vargas-Requena, C.L.; Bustos-Jaimes, I.; Alvarez-Parrilla, A.E. Polyphenolic compounds and digestive enzymes: In vitro non-covalent interactions. Molecules 2017, 22, 669. [CrossRef]

38. Menghini, L.; Leporini, L.; Vecchiotti, G.; Locatelli, M.; Carradori, S.; Ferrante, C.; Zengin, G.; Recinella, L.; Chiavaroli, A.; Leone, S.; et al. Crocus sativus L. stigmas and byproducts: Qualitative fingerprint, antioxidant potentials and enzyme inhibitory activities. Food Res. Int. 2018, 109, 91-98. [CrossRef]

39. Kondrashev, S.; Nesterova, N.; Luzin, A.; Kochanov, V.; Luzina, A.; Matyushin, A. Qualitative and Quantitative Assay of Hydroxycinnamates of Prunus spinosa L. Pharmacogn. J. 2020, 12, 157-161. [CrossRef]

40. Lee, J.; Scagel, C.F. Chicoric acid: Chemistry, distribution, and production. Front. Chem. 2013, 1, 40. [CrossRef]

41. Jabłońska-Trypuć, A.; Wydro, U.; Wołejko, E.; Świderski, G.; Lewandowski, W. Biological Activity of New Cichoric Acid-Metal Complexes in Bacterial Strains, Yeast-Like Fungi, and Human Cell Cultures In Vitro. Qualitative and Quantitative Assay of Hydroxycinnamates of Prunus Spinosa, L. Nutrients 2020, 12, 154. [CrossRef] [PubMed]

42. Liu, Q.; Chen, Y.; Shen, C.; Xiao, Y.; Wang, Y.; Liu, Z.; Liu, X. Chicoric acid supplementation prevents systemic inflammationinduced memory impairment and amyloidogenesis via inhibition of NF-kB. FASEB J. 2017, 31, 1494-1507. [CrossRef] [PubMed]

43. Tsai, Y.-L.; Chiu, C.-C.; Chen, J.Y.-F.; Chan, K.-C.; Lin, S.-D. Cytotoxic effects of Echinacea purpurea flower extracts and cichoric acid on human colon cancer cells through induction of apoptosis. J. Ethnopharmacol. 2012, 143, 914-919. [CrossRef]

44. Wang, Y.; Xie, G.; Liu, Q.; Duan, X.; Liu, Z.; Liu, X. Pharmacokinetics, tissue distribution, and plasma protein binding study of chicoric acid by HPLC-MS/MS. J. Chromatogr. B 2016, 1031, 139-145. [CrossRef] [PubMed]

45. Adem, S.; Eyupoglu, V.; Sarfraz, I.; Rasul, A.; Zahoor, A.F.; Ali, M.; Abdalla, M.; Ibrahim, I.M.; Elfiky, A.A. Caffeic acid derivatives (CAFDs) as inhibitors of SARS-CoV-2: CAFDs-based functional foods as a potential alternative approach to combat COVID-19. Phytomedicine 2021, 85, 153310. [CrossRef]

46. Bahar, B.; O’Doherty, J.; Hayes, M.; Sweeney, T. Extracts of brown seaweeds can attenuate the bacterial lipopolysaccharide-induced pro-inflammatory response in the porcine colon ex vivo. J. Anim. Sci. 2012, 90 (Suppl. 4), 46-48. [CrossRef]

47. Aoki, T.; Narumiya, S. Prostaglandin E 2-EP2 signaling as a node of chronic inflammation in the colon tumor microenvironment. Inflamm. Regener. 2017, 37, 1-5. [CrossRef]

48. Hummel, D.M.; Fetahu, I.S.; Gröschel, C.; Manhardt, T.; Kállay, E. Role of proinflammatory cytokines on expression of vitamin D metabolism and target genes in colon cancer cells. J. Steroid Biochem. Mol. Biol. 2014, 144, 91-95. [CrossRef] [PubMed]

49. Murdocca, M.; De Masi, C.; Pucci, S.; Mango, R.; Novelli, G.; Di Natale, C.; Sangiuolo, F. LOX-1 and cancer: An indissoluble liaison. Cancer Gene Ther. 2021, 1-11.

50. Owczarek, K.; Lewandowska, U. The impact of dietary polyphenols on COX-2 expression in colorectal cancer. Nutr. Cancer 2017, 69, 1105-1118. [CrossRef]

51. Lee, J.; Chang, C.; Liu, I.; Chi, T.; Yu, H.; Cheng, J. Changes in endogenous monoamines in aged rats. Clin. Exp. Pharmacol. Physiol. 2001, 28, 285-289. [CrossRef]

52. Orlando, G.; Chiavaroli, A.; Leone, S.; Brunetti, L.; Politi, M.; Menghini, L.; Recinella, L.; Ferrante, C. Inhibitory effects induced by Vicia faba, Uncaria rhyncophylla, and Glycyrrhiza glabra water extracts on oxidative stress biomarkers and dopamine turnover in HypoE22 cells and isolated rat striatum challenged with 6-hydroxydopamine. Antioxidants 2019, 8, 602. [CrossRef]

53. Bao, X.-X.; Ma, H.-H.; Ding, H.; Li, W.-W.; Zhu, M. Preliminary optimization of a Chinese herbal medicine formula based on the neuroprotective effects in a rat model of rotenone-induced Parkinson's disease. J. Integr. Med. 2018, 16, 290-296. [CrossRef]

54. Ye, S.; Koon, H.K.; Fan, W.; Xu, Y.; Wei, W.; Xu, C.; Cai, J. Effect of a traditional chinese herbal medicine formulation on cell survival and apoptosis of MPP+-treated MES 23.5 dopaminergic cells. Parkinson's Dis. 2017, 2017, 4764212. [CrossRef]

55. Liu, Q.; Fang, J.; Chen, P.; Die, Y.; Wang, J.; Liu, Z.; Liu, X. Chicoric acid improves neuron survival against inflammation by promoting mitochondrial function and energy metabolism. Food Funct. 2019, 10, 6157-6169. [CrossRef]

56. Hussain, M.; Jabeen, N.; Amanullah, A.; Baig, A.A.; Aziz, B.; Shabbir, S.; Raza, F.; Uddin, N. Molecular docking between human TMPRSS2 and SARS-CoV-2 spike protein: Conformation and intermolecular interactions. AIMS Microbiol. 2020, 6, 350. [CrossRef] [PubMed]

57. Arteaga-Crespo, Y.; Radice, M.; Bravo-Sanchez, L.R.; García-Quintana, Y.; Scalvenzi, L. Optimisation of ultrasound-assisted extraction of phenolic antioxidants from Ilex guayusa Loes. leaves using response surface methodology. Heliyon 2020, 6, e03043. [CrossRef] 
58. Uysal, S.; Zengin, G.; Locatelli, M.; Bahadori, M.B.; Mocan, A.; Bellagamba, G.; De Luca, E.; Mollica, A.; Aktumsek, A. Cytotoxic and enzyme inhibitory potential of two Potentilla species (P. speciosa L. and P. reptans Willd.) and their chemical composition. Front. Pharmacol. 2017, 8, 290. [CrossRef] [PubMed]

59. Zengin, G.; Ceylan, R.; Sinan, K.I.; Ak, G.; Uysal, S.; Mahomoodally, M.F.; Lobine, D.; Aktumsek, A.; Cziáky, Z.; Jeko, J.; et al. Network analysis, chemical characterization, antioxidant and enzyme inhibitory effects of foxglove (Digitalis cariensis Boiss. ex Jaub. \& Spach): A novel raw material for pharmaceutical applications. J. Pharm. Biomed. Anal. 2020, 191, 113614. [PubMed]

60. Recinella, L.; Chiavaroli, A.; di Giacomo, V.; Antolini, M.D.; Acquaviva, A.; Leone, S.; Brunetti, L.; Menghini, L.; Ak, G.; Zengin, G.; et al. Anti-Inflammatory and Neuromodulatory Effects Induced by Tanacetum parthenium Water Extract: Results from In Silico, In Vitro and Ex Vivo Studies. Molecules 2021, 26, 22. [CrossRef] [PubMed]

61. Ferrante, C.; Orlando, G.; Recinella, L.; Leone, S.; Chiavaroli, A.; Di Nisio, C.; Shohreh, R.; Manippa, F.; Ricciuti, A.; Vacca, M. Central apelin-13 administration modulates hypothalamic control of feeding. J. Biol. Regul. Homeost. Agents 2016, 30 , 883-888. [PubMed]

62. Angelini, P.; Matei, F.; Flores, G.A.; Pellegrino, R.M.; Vuguziga, L.; Venanzoni, R.; Tirillini, B.; Emiliani, C.; Orlando, G.; Menghini, L.; et al. Metabolomic Profiling, Antioxidant and Antimicrobial Activity of Bidens pilosa. Processes 2021, 9, 903. [CrossRef]

63. Angelini, P.; Venanzoni, R.; Angeles Flores, G.; Tirillini, B.; Orlando, G.; Recinella, L.; Chiavaroli, A.; Brunetti, L.; Leone, S.; Di Simone, S.C.; et al. Evaluation of Antioxidant, Antimicrobial and Tyrosinase Inhibitory Activities of Extracts from Tricholosporum goniospermum, an Edible Wild Mushroom. Antibiotics 2020, 9, 513. [CrossRef] [PubMed] 